\title{
correspondence
}

\section{Oklo today}

SIR,-It is obviously of great interest to trace the fate of the fission products from the natural nuclear reactor at the Oklo River, Gabon (17 March, page 206), but if parallels are to be drawn with present day reactors and radioactive wastes, then one further fact needs to be stressed, namely that today's world is seething with complex living organisms. $1.8 \times 10^{9}$ years ago there were, in all probability, only comparatively simple organisms.

Today's organisms have very considerable powers of dispersal so that any radioactive chemical which enters one organism may be transported a considerable distance as it travels through the food chain; and higher organisms (mammals for example) are 1,000 times more sensitive to radiation than are the simpler forms of life (such as bacteria) which might well have existed at Oklo. To argue that since we, as living organisms, survived Oklo we can also survive comparable releases of radioactivity today is dangerously misleading. Of course life will survive the next few hundred years, but the question is at what cost to the particular forms of life that we consider to be important such as our own species.

\section{Malcolm Eimmunds}

\section{Biology Division,}

\section{Preston Polytechnic, UK}

\section{Scientists as administrators}

SIR,-Y Your issue of 27 January, 1977 carries two articles which are complementary. The first is abstracted from Sir Hermann. Bondi's broadcast and points out the very limited movement of scientists to administrative posts in the Civil Service and in industry in general; the second, by Kenneth Mellaniby, provides the apparent paradox by emphasising that, in war-time, academics immediately turned to administrative tasks with great success. Mellanby goes on to ask why academics do not do this now.

In war, there was one clear objective - the enemy. The desired end was agreed by all, and a constant beacon to steer by Not so now when national goals are confused and form the subject of bitter political wrangling and power-seeking. Yet, if, for example, the intensive cultivation of the Highlands of Scotland was essential for national survival, I have not the slightest doubt that the scientific ability needed to do this would flow as readily and effectively as it did to defeat the Nazis.

Sir Hermann points out that scientists as administrators must be seen to be badly needed. Rightly or wrongly the scientist is still often made to feel a poor relation of the arts man in respect of administrative ability, though not in organisations such as Unilever and ICI whose effectiveness as innovators is remarkable.

This will not be changed simply by altering the structures of science courses, but by a positive effort to encourage scientists to move to administration. I would like to see advertisements for administrators, stating that applicants with a scientific and technological background are preferred, and would be given the appropriate training if needed. After all, professors of science and technology and the heads of departments in government scientific institutes began life as rather shy, young scientists: most are now capable administrators and few would doubt their capacity for argumentwritten and spoken-sharpened and tempered as it is by the ceaseless battle with well-meaning but uncomprehending, non-scientific administrators.

\section{P. J. Heald}

Department of Biochemistry, The Todd Centre, Glasgow

\section{Stamps of scientific interest}

The British Post Office marked the centenary of the Royal Institute of Chemistry by issuing a set of four multicoloured stamps last month, each featuring a Nobel prize-winning development.

The two shown, at $8 \frac{1}{2} \mathrm{p}$ and $11 \mathrm{p}$, commemorate Professor Sir Derek Barton's work on conformational analysis and the development of partition chromatography by Professor A. J. P. Martin and R. L. M. Synge. They depict the central part of the chemical structure of a steroid against a background of pharmaceutical products and instruments; and a graph, showing the different amounts of substances in a complex mixture separated by partition chromatography superimposed on the kind of pattern produced by the technique when used on paper.

The other two stamps, at $10 p$ and $13 p$, commemorate the work of Sir Norman Haworth, which resulted in the first synthetic vitamin identical to that occurring in natural citrus fruits, and the work of Professors Sir William and Sir Lawrence Bragg, the father and son who developed crystallography.

Australia last year issued a set of four $18 \mathrm{c}$ stamps featuring famous Australian

\section{Cutting out abbreviations}

SrR,--Adrian Smith's suggestion (10 February, page 492) that abbreviated titles of periodicals be replaced by full and accurate citations, will have the sympathy of authors, editors and secretaries. This proposal has already been tested in practice. The British Medical Journal stopped abbreviating titles in April 1969. A working party set up in 1968 by a Conference of Medical Editors" "strongly recommended all journals to follow suit: a majority of (medical) editors agreed to do so". The working party also reported that with full citations "the increase in type area is maximally $2 \%$ and usually much less". The editors of the British Medical Journal also reported that "the saving in editorial time is enormous".

When the effective use of public money on scientific research is increasingly coming under close scrutiny, any time spent by authors and indeed editors, themselves very of ten active in research, on such a mundane and unproductive task must be seriously questioned. If any economies result from the present practice, they must only be reflected in the balance sheets of publishing companies.

\section{D. INCOLL}

Department of Plant Sciences, University of Leeds, UK

scientists, three of whom ironically were born in England. Sir Thomas Laby (18801946) did much of his research on the possible uses of radium in combating cancer. Professor Griffith Taylor (18801963) joined the Commonwealth Weather Service in 1910 as a physiographer and then joined Scott's Antarctic expedition.

The other stamps depict the ornithologist John Gould (1804-81), regarded as the father of Australian bird study, and the anthropologist, Sir Baldwin Spencer (1860-1929), who studied the tribal customs of Australian aborigines. Ian $\mathbf{F}$. Finlay

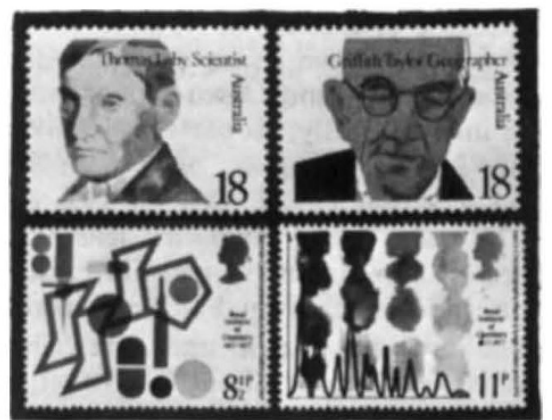

